\title{
Poprawa szczelności płaszcza cementowego za pomocą innowacyjnych dodatków antymigracyjnych
}

\begin{abstract}
Podczas wiercenia otworów bardzo istotne jest uzyskanie odpowiedniej szczelności po odwierceniu i zacementowaniu otworu. Wyeliminowanie niekontrolowanych przepływów mediów gazowych w przestrzeni pierścieniowej możliwe jest poprzez uszczelnienie określonego interwału odpowiednio zaprojektowanym zaczynem cementowym. Aby uzyskać takie uszczelnienie należy odpowiednio zaprojektować recepturę zaczynu poprzez przeprowadzenie badań, a następnie odpowiedni dobór dodatków i domieszek do zaczynów. Dostępne w ostatnich latach innowacyjne dodatki przeciwdziałające migracji gazu poddane zostały badaniom w Instytucie Nafty i Gazu - Państwowym Instytucie Badawczym w celu określenia ich wpływu na parametry technologiczne zaczynu cementowego, a tym samym w celu określenia poprawy szczelności płaszcza cementowego. Dostępne dodatki antymigracyjne to głównie polimery wielkocząsteczkowe. Środki takie z reguły powinny wywierać korzystny wpływ na ograniczenie lub wyeliminowanie możliwości zachodzenia niekontrolowanych przepływów gazu przez wiążący i związany zaczyn cementowy. Jednak bez wykonania szczegółowych badań parametrów technologicznych zaczynów cementowych z wprowadzanymi na rynek środkami nie jest możliwe ich stosowanie w warunkach otworowych. W związku z powyższym w artykule przedstawiono wyniki prac nad oceną parametrów technologicznych zaczynów cementowych z innowacyjnymi środkami antymigracyjnymi. Celem realizowanych prac badawczych było sprawdzenie działania dodatków oraz modyfikacje zaczynów, mające na celu poprawę szczelności płaszcza cementowego wskutek odpowiedniego doboru receptur dla danych warunków otworowych. Oczekiwane rezultaty uzyskano poprzez zastosowanie dostępnych dodatków przeciwdziałających migracji gazu przez świeży i stwardniały zaczyn cementowy. Prowadzone prace badawcze miały na celu określenie skuteczności w przeciwdziałaniu migracji gazu zaczynów modyfikowanych przy użyciu nowych środków oraz ich wpływu na poprawę szczelności płaszcza cementowego.
\end{abstract}

Słowa kluczowe: migracja gazu, zaczyn cementowy, środki zapobiegające migracji gazu, cementowanie otworów wiertniczych, parametry zaczynu, wiertnictwo.

\section{Improving the cement sheath sealing by innovative gas migration control additives}

The elimination of uncontrolled gas flows in the annular space is possible by sealing a specific interval with a properly designed cement slurry. In order to obtain such a seal, the cement slurry formulation should be properly designed by conducting laboratory tests and then the appropriate selection of additives and admixtures for cement slurries. Innovative gas migration control additives available in recent years have been tested in the Oil and Gas Institute - National Research Institute in order to determine their impact on the technological parameters of cement slurry, and thus to determine the improvement of the tightness of the cement sheath. Available anti-migration additives are mainly high molecular weight polymers. Such additives generally should have a beneficial effect on reducing or eliminating the possibility of uncontrolled gas flows through binding and set cement slurry. However, without performing detailed tests of the technological parameters of cement slurries with the available additives, it is not possible to use them in borehole conditions. Therefore, the paper presents the results of laboratory tests on the evaluation of technological parameters of cement slurries with innovative gas migration control additives. The purpose of the research work was the evaluation of additives and modifications of cement slurries in order to improve of tightness of the cement sheath due to the appropriate selection of recipes for the given borehole conditions. The expected results were obtained by the use of available additives which prevented gas migration through fresh and set cement slurry. The aim of the research work was to determine the effectiveness of modified cement slurries with new additives to prevent gas migration and their impact on improving the tightness of the cement sheath.

Key words: gas migration, cement slurry, gas migration control additives, well cementing, cement slurry parameters, drilling. 


\section{Wprowadzenie}

Ze względu na to, że skuteczność zabiegu cementowania rur okładzinowych w znacznym stopniu zależy od odpowiedniego doboru parametrów zaczynu uszczelniającego, wymaga się wprowadzania innowacyjnych i coraz skuteczniejszych środków regulujących powyższe właściwości. Przeznaczenie zaczynu cementowego do uszczelniania otworów wiertniczych wymusza wprowadzanie modyfikacji, skutkujących uzyskaniem wymaganych parametrów reologicznych, gęstości dostosowanej do konkretnych warunków geologiczno-złożowych oraz niskiej filtracji. Powstały z odpowiednio zaprojektowanego zaczynu płaszcz cementowy powinien się charakteryzować wysokimi parametrami mechanicznymi oraz być nieprzepuszczalny dla gazu $[7,12,21]$.

Jednym z problemów, z którymi zmagają się serwisy cementacyjne jest możliwość wystąpienia niekontrolowanych przepływów gazu po zacementowaniu, będących wynikiem braku szczelności płaszcza cementowego. W związku z tym projektując recepturę zaczynu mającego za zadanie ograniczenie bądź wyeliminowanie migracji i ekshalacji gazu, należy dostosować dany skład do warunków geologicznych. W tym celu zaczyn powinien posiadać:

- odpowiednio dobraną gęstość oraz parametry reologiczne, a także konsystencję i czas przetłaczalności na poziomie zapewniającym bezawaryjne zatłoczenie zaczynu do otworu i wytłoczenie w miejsce założone w projekcie,
- odpowiedni dla warunków panujących w otworze czas wiązania zaczynu,

- odpowiednią stabilność sedymentacyjną oraz niską filtrację,

- krótki czas przejścia konsystencji zaczynu od $30 \mathrm{Bc}$ do $100 \mathrm{Bc}$,

- krótki czas przejścia (ang. Transition Time) od wartości $50 \mathrm{~Pa}$ do wartości $250 \mathrm{~Pa}$ podczas narastania statycznej wytrzymałości strukturalnej,

- wzrost objętości zaczynu podczas wiązania (ekspansja zaczynu),

- odpowiednią wytrzymałość mechaniczną stwardniałego zaczynu uszczelniającego,

- jak najmniejszą przepuszczalność dla gazu przez stwardniały zaczyn uszczelniający,

- jak najmniejszą porowatość mikrostruktury stwardniałego zaczynu uszczelniającego,

- maksymalnie skompaktowaną strukturę stwardniałego zaczynu uszczelniającego,

- możliwie prostą technologię sporządzania zaczynu w warunkach przemysłowych [3, 6, 7, 9, 10, 22].

$\mathrm{Z}$ uwagi na to, że receptury przeznaczone do uszczelniania otworów o podwyższonym ryzyku wystąpienia migracji i ekshalacji gazu muszą spełniać szereg wymagań, niezbędne jest prowadzenie specjalistycznych badań, które pozwalają zaprojektować recepturę dla konkretnych warunków geologiczno-technicznych.

\section{Przeciwdziałanie migracji gazu przez zaczyn cementowy}

Określenie możliwości przeciwdziałania migracji gazu przez wiążący zaczyn cementowy jest możliwe za pomocą analizatora UCA SGSM (fotografia 1). Dzięki temu urządzeniu możliwe jest zbadanie narastania statycznej wytrzymałości strukturalnej zaczynu w warunkach otworopodobnych. Urządzenie umożliwia określenie odstępu czasowego od pierwszego wykonanego pomiaru SWS (statycznej wytrzymałości strukturalnej) do czasu, w którym zaczyn cementowy uzyska konsystencję uniemożliwiającą powstawanie nowych kanałów gazowych [11, 10, 15, 17, 19]. Zaczyn cementowy transformuje $\mathrm{z}$ fazy ciekłej, poprzez żelową, aż do powstania fazy stałej (stwardniały zaczyn cementowy). Cały ten cykl zmian ma miejsce po wytłoczeniu zaczynu poza rury okładzinowe. Podczas tych zmian zaczyn nie zachowuje się ani jako ciecz, ani jako faza stała, wykazuje jednak cechy możliwe do przypisania obu tym stanom jednocześnie. Podczas transformacji, w związku z hydratacją zaczynu, jego statyczna wytrzymałość strukturalna wzrasta. Odczyt pierwszej wartości SWS następuje w początkowym punkcie przechodzenia ze stanu ciekłego (gdy zaczyn jest w stanie w pełni przekazywać ciśnienie hydrostatyczne) do stanu, w którym następuje początek spadku ciśnienia hydrostatycznego [1, 2, 4, 11]. Doświadczalnie wyznaczona wartość odpowiadająca temu punktowi wynosi $50 \mathrm{~Pa}$ (zaznaczenie A, rysunek 1). Następne punkty pomiarowe rejestrowane są $\mathrm{w}$ określonych interwałach czasowych, aż do punktu, w którym zaczyn cementowy traci sposobność przekazywania ciśnienia hydrostatycznego. Punktem tym jest czas początku okresu przejściowego wiązania, a jego wartość wynosi $250 \mathrm{~Pa}$ (zaznaczenie B, rysunek 1) [5, 11, 15].

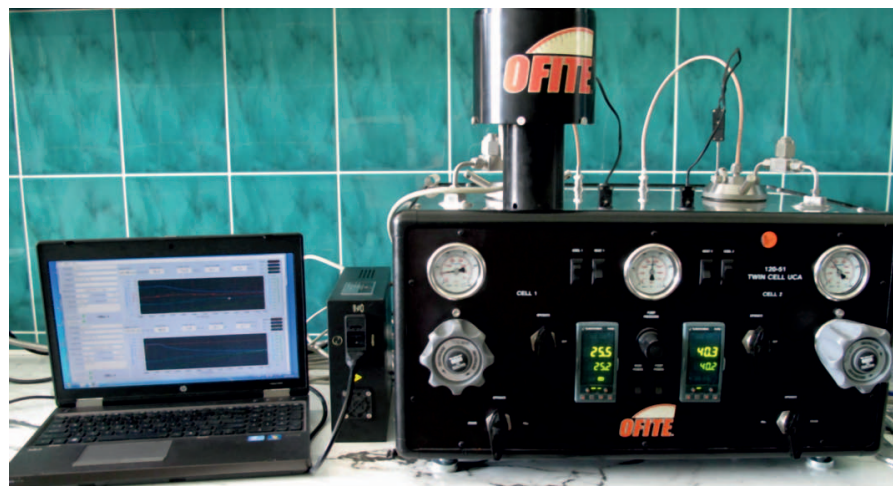

Fot. 1. Ultradźwiękowy analizator cementu z modułem SGSM 


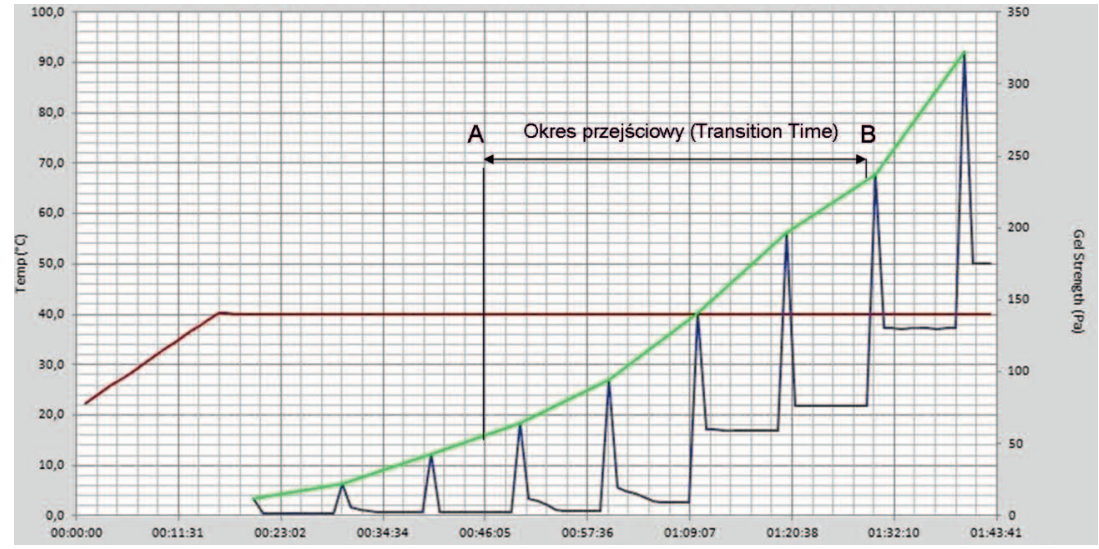

Rys. 1. Okres przejściowy zaczynu uszczelniającego

ciwdziałaniu ciśnieniu złożowemu poprzez ciśnienie hydrostatyczne, wytwarzając od samego początku strukturę o małej przepuszczalności, zabezpieczając jednocześnie ewentualny dopływ gazu. W zaczynach typu RAS następuje gwałtowne gęstnienie od wartości $30 \mathrm{Bc}$ do $100 \mathrm{Bc}$ (rysunek 2) $[7,13,18]$. Wiązanie zaczynu polega na rehydratyzacji minerałów podlegających hydratyzacji. Zaczyny RAS wykazują niską temperaturę zanim nastąpi wiązanie, czyli w momencie, gdy konsystencja zaczynu wzrasta do wartości $100 \mathrm{Bc}$ w ciągu kilku minut [18]. Podczas wiązania następuje wzrost temperatury (rysunek 2) oraz

W celu wyeliminowania migracji gazu przez wiążący zaczyn cementowy, a tym samym zwiększenia szczelności płaszcza cementowego wymagane jest stosowanie zaczynów z dodatkami antymigracyjnymi.

Receptury stosowane do uszczelniania kolumn rur okładzinowych w rejonach występowania migracji gazu są dosyć skomplikowane. Ekshalacje gazu pojawiają się zazwyczaj w obszarach, gdzie problemem podczas wykonywania prac wiertniczych jest występowanie w profilach litologicznych warstw sypkich. Bardzo często ma to miejsce na niewielkich głębokościach. Z uwagi na powyższe aspekty, receptury używane do cementowania zawierają zazwyczaj dodatki polimerów, mikrocementu i lateksu w celu doszczelnienia struktury płaszcza cementowego [20, 23, 24]. W celu zwiększenia efektywności uszczelniania rur okładzinowych, w rejonach o podwyższonym ryzyku występowania migracji gazu stosuje się dodatki do zaczynów umożliwiające zaprojektowanie zaczynów, takich jak:

- zaczyny typu gasblock - jest to grupa zaczynów, których stosowanie rekomenduje się w rejonie o podwyższonym ryzyku wystąpienia migracji i ekshalacji gazu. Przy projektowaniu i sporządzaniu zaczynów uszczelniających typu gasblock, należy uwzględniać opóźnienie czasu budowania początkowej statycznej wytrzymałości strukturalnej. Powyższa cecha zaczynu ma na celu wydłużenie czasu równoważenia ciśnienia złożowego przez ciśnienie hydrostatyczne zaczynu uszczelniającego. Zaczyny te są modyfikowane w taki sposób, aby czasy przejścia (okresy przejściowe transition time (rysunek 1) były jak najkrótsze (często poniżej $60 \mathrm{mi}$ nut), pozwala to wyeliminować możliwość wtargnięcia gazu w strukturę wiążącego płaszcza cementowego $[8,13,14]$.

- zaczyny specjalne typu Right Angle Set - to grupa zaczynów bardzo przydatnych z punktu widzenia przeciwdziałania możliwości powstawania migracji gazu. Zaczyny RAS są zdyspergowanymi systemami niewykazującymi progresywnych tendencji do żelowania. Zaczyny cementowe tego rodzaju wykazują szybkie wiązanie z uwagi na gwałtowną kinetykę reakcji [18]. Ich działanie polega na ciągłym przewzrost konsystencji zaczynu wskutek egzotermicznego charakteru reakcji hydratacji. W literaturze [18] podaje się, że wytrzymałość strukturalna tego rodzaju zaczynów różni się od wytrzymałości ocenianej w czasie operacji cementowania. Pomocna jest również obecność w zaczynie dodatków upłynniających oraz obniżających wielkość filtracji z uwagi na ich działanie opóźniające [12].

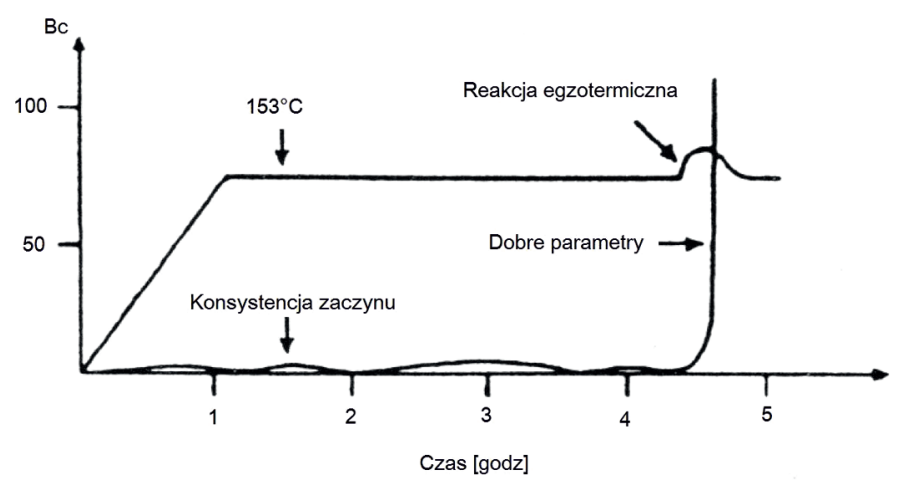

Rys. 2. Przebieg gęstnienia zaczynu typu „RAS”

Proces migracji gazu wewnątrz płaszcza cementowego następuje wskutek „wtargnięcia” gazu w strukturę wiążącego zaczynu i wytworzenia „kanalików” gazowych. Jest to związane z obniżeniem się ciśnienia hydrostatycznego wiążącego zaczynu cementowego poniżej wartości ciśnienia złożowego. W celu wyeliminowania tego zjawiska parametry zaczynów cementowych są regulowane za pomocą różnego rodzaju dodatków. Są to głównie związki polimerów wielkocząsteczkowych o „zakodowanym” przez dystrybutorów składzie. Działanie tych środków opiera się między innymi na regulacji wody wolnej zaczynu, regulacji filtracji oraz działaniu mającym na celu budowanie wytrzymałości strukturalnej zaczynu w bardzo krótkim czasie. Analiza powyższych mechanizmów reakcji zachodzących w strukturze wiążącego zaczynu cementowego wymusza stosowanie innowacyjnych dodatków antymigracyjnych w celu wyeliminowania migracji gazu przez świeży i stwardniały zaczyn cementowy, a tym samym zwiększenie szczelności płaszcza cementowego [16]. 


\section{Przebieg prac badawczych}

Badania, których celem było przeprowadzenie analizy możliwości zwiększenia szczelności płaszcza cementowego za pomocą innowacyjnych dodatków antymigracyjnych wykonano w Laboratorium Zaczynów Uszczelniających INiG - PIB na podstawie norm: PN-85/G-02320 Cementy $i$ zaczyny cementowe do cementowania w otworach wiertniczych; PN-EN 10426-2 Przemyst naftowy i gazowniczy. Cementy i materiaty do cementowania otworów. Część 2: Badania cementów wiertniczych oraz API SPEC 10 Specification for materials and testing for well cements.

Przedstawiony w publikacji cykl badawczy polegał na wykazaniu możliwości zwiększenia szczelności płaszcza cementowego poprzez zastosowanie różnego rodzaju dodatków antymigracyjnych. Do badań wytypowane zostały receptury dla warunków otworowych o temperaturze $25^{\circ} \mathrm{C}$ i $50^{\circ} \mathrm{C}$ i ciśnieniu odpowiednio 3 oraz $15 \mathrm{MPa}$. Zaczyny sporządzone zostały przy użyciu cementu portlandzkiego klasy CEM I 32,5R. Do sporządzania zaczynów użyto wodociągowej wody zarobowej.

Wykonane zostały podstawowe badania parametrów decydujących o efektywności uszczelniania kolumn rur okładzinowych, tj. gęstość zaczynu, parametry reologiczne, odstój wody, rozlewność, filtracja zaczynu oraz czas gęstnienia w warunkach otworopodobnych. W celu zbadania właściwości antymigracyjnych badanych zaczynów cementowych przeprowadzono badania statycznej wytrzymałości strukturalnej za pomocą urządzenia UCA SGSM (Static
Gel Strength Measurment). Powyższe testy pozwoliły wykazać efektywność działania środków mających za zadanie wyeliminowanie migracji gazu przez wiążący i związany zaczyn cementowy. W kolejnym etapie prac wykonano badania przepuszczalności i porowatości, co umożliwiło ocenę wpływu dodatków przeciwdziałających migracji gazu na zwiększenie szczelności stwardniałego zaczynu cementowego.

Cykl badawczy rozpoczęto od wytypowania zaczynu bazowego (Baz) dla warunków otworowych o określonej temperaturze i ciśnieniu. Receptura została poddana modyfikacjom polegającym na zastosowaniu różnego rodzaju dodatków antymigracyjnych (AM 1, AM 2, AM 3, AM 4) w ilości 7\% (wagowo w stosunku do masy cementu). Receptury zaczynów oraz ilościowe zawartości poszczególnych dodatków i domieszek zestawiono $\mathrm{w}$ tablicy 1 , natomiast $\mathrm{w}$ tablicy 2 przedstawiono

Tablica. 1. Receptury zaczynów cementowych

\begin{tabular}{|c|c|}
\hline Temperatura $25^{\circ} \mathrm{C}$, ciśnienie $3 \mathrm{MPa}$ & Temperatura $50^{\circ} \mathrm{C}$, ciśnienie $15 \mathrm{MPa}$ \\
\hline $\begin{array}{l}\text { Składniki stałe } \\
\text { - w/c }=0,52 \\
\text { - dodatek odpieniający }-0,2 \% \\
\text { - dodatek upłynniający }-0,4 \% \\
\text { - dodatek antymigracyjny }{ }^{*}-\mathbf{7 , 0} \\
\text { - } \mathrm{CaCl}_{2}-1,0 \% \\
\text { - mikrocement }-5,0 \% \\
\text { - cement CEM I } 32,5 \mathrm{R}-100 \%\end{array}$ & $\begin{array}{l}\text { Składniki stałe } \\
\text { - w/c }=0,54 \\
\text { - dodatek odpieniający }-0,3 \% \\
\text { - dodatek upłynniający }-0,3 \% \\
\text { - dodatek antymigracyjny }{ }^{*}-\mathbf{7 , 0} \\
\text { - } \mathrm{CaCl}_{2}-1,0 \% \\
\text { - mikrocement }-5,0 \% \\
\text { - cement CEM I 32,5R - 100\% } \\
\text { - dodatek spęczniający }-0,3 \%\end{array}$ \\
\hline
\end{tabular}

* Stała ilość dodatku antymigracyjnego, zmienny rodzaj zastosowanego środka antymigracyjnego (AM1, AM2, AM3, AM4).

Tablica 2. Parametry decydujące o efektywności uszczelniania zaczynów cementowych

\begin{tabular}{|c|c|c|c|c|c|c|c|c|c|c|c|c|c|c|}
\hline \multirow{2}{*}{$\begin{array}{l}\text { Symbol } \\
\text { zaczynu }\end{array}$} & \multirow{2}{*}{$\begin{array}{l}\text { Rodzaj } \\
\text { cementu }\end{array}$} & \multirow{2}{*}{$\begin{array}{c}\text { Tempera- } \\
\text { tura }\left[{ }^{\circ} \mathrm{C}\right] \\
\text { Ciśnienie } \\
\text { hydratacji } \\
{[\mathrm{MPa}]}\end{array}$} & \multirow{2}{*}{$\begin{array}{l}\text { Gęstość } \\
{\left[\mathrm{kg} / \mathrm{m}^{3}\right]}\end{array}$} & \multirow{2}{*}{$\begin{array}{c}\text { Rozlew- } \\
\text { ność }\end{array}$} & \multirow{2}{*}{$\begin{array}{c}\begin{array}{c}\text { Odstój } \\
\text { wody }\end{array} \\
{[\%]}\end{array}$} & \multirow{2}{*}{$\begin{array}{l}\text { Filtracja } \\
\\
{\left[\mathrm{cm}^{3} /\right.} \\
30 \mathrm{~min}]\end{array}$} & \multicolumn{2}{|c|}{$\begin{array}{l}\text { Czas gęstnienia* } \\
\text { [godz:min] }\end{array}$} & \multicolumn{6}{|c|}{$\begin{array}{c}\text { Odczyty z aparatu Fann } \\
{[\mathrm{obr} / \mathrm{min}]}\end{array}$} \\
\hline & & & & & & & $30 \mathrm{Bc}$ & $100 \mathrm{Bc}$ & 600 & 300 & 200 & 100 & 6 & 3 \\
\hline $\mathrm{Baz}^{* *}$ & \multirow{10}{*}{$\begin{array}{c}\text { Cement } \\
\text { CEM I } \\
32,5 \mathrm{R}\end{array}$} & \multirow{5}{*}{$\begin{array}{c}25^{\circ} \mathrm{C} \\
3 \mathrm{MPa}\end{array}$} & 1800 & 275 & 1,0 & 350 & $01: 50$ & $03: 30$ & 220 & 190 & 140 & 92 & 15 & 8 \\
\hline AM1 & & & 1800 & 270 & 0,2 & 491 & $00: 37$ & $02: 41$ & 68 & 36 & 25 & 14 & 4 & 3 \\
\hline AM2 & & & 1800 & 265 & 0,2 & 429 & $02: 03$ & $03: 11$ & 68 & 37 & 26 & 15 & 4 & 3 \\
\hline AM 3 & & & 1800 & 265 & 0,2 & 108 & $01: 32$ & $02: 20$ & 152 & 84 & 59 & 33 & 7 & 5 \\
\hline $\mathrm{AM} 4$ & & & 1800 & 250 & 0,0 & 45 & 01:46 & $02: 19$ & 230 & 132 & 100 & 58 & 9 & 7 \\
\hline $\mathrm{Baz}^{* *}$ & & \multirow{5}{*}{$\begin{array}{c}50^{\circ} \mathrm{C} \\
15 \mathrm{MPa}\end{array}$} & 1800 & 255 & 0,5 & 310 & $03: 10$ & 05:05 & 250 & 215 & 165 & 120 & 30 & 12 \\
\hline AM 1 & & & 1800 & 250 & 0,0 & 428 & $02: 50$ & $04: 50$ & 69 & 39 & 29 & 20 & 9 & 8 \\
\hline AM 2 & & & 1800 & 240 & 0,0 & 348 & $02: 44$ & $04: 54$ & 72 & 46 & 36 & 25 & 14 & 13 \\
\hline AM 3 & & & 1800 & 240 & 0,0 & 18 & $04: 15$ & $04: 45$ & 160 & 91 & 64 & 37 & 9 & 7 \\
\hline AM 4 & & & 1810 & 230 & 0,0 & 12 & $03: 59$ & 04:09 & 192 & 110 & 79 & 45 & 7 & 5 \\
\hline
\end{tabular}

${ }^{*}$ Czas dojścia do temperatury: $25^{\circ} \mathrm{C}=10 \mathrm{~min}$; do temperatury $50^{\circ} \mathrm{C}=30 \mathrm{~min}$.

** Zaczyn bazowy (Baz) to zaczyn bez dodatku antymigracyjnego. 
Tablica 3. Parametry reologiczne zaczynów cementowych

\begin{tabular}{|c|c|c|c|c|c|c|c|c|c|c|c|}
\hline \multirow{2}{*}{$\begin{array}{l}\text { Model } \\
\text { reologiczny }\end{array}$} & \multirow{2}{*}{$\begin{array}{l}\text { Parametry } \\
\text { reologiczne }\end{array}$} & \multicolumn{10}{|c|}{ Zaczyn numer } \\
\hline & & Baz 1 & AM 1 & AM 2 & AM 3 & AM 4 & Baz 2 & AM 1 & AM 2 & AM 3 & $\mathrm{AM} 4$ \\
\hline \multirow{3}{*}{$\begin{array}{l}\text { Model } \\
\text { Cassona }\end{array}$} & $\begin{array}{l}\text { Lepkość } \\
\text { Cassona }[\mathrm{Pa} \cdot \mathrm{s}]\end{array}$ & 0,0928 & 0,0238 & 0,0241 & 0,0586 & 0,0929 & 0,0898 & 0,0165 & 0,0135 & 0,0579 & 0,0794 \\
\hline & $\begin{array}{l}\text { Granica } \\
\text { płynięcia [Pa] }\end{array}$ & 4,4633 & 0,6886 & 0,6993 & 1,1030 & 1,6843 & 8,7546 & 2,6955 & 4,9739 & 1,7486 & 1,0811 \\
\hline & $\begin{array}{l}\text { Współczynnik } \\
\text { korelacji [-] }\end{array}$ & 0,9343 & 0,9975 & 0,9984 & 0,9998 & 0,9982 & 0,9368 & 0,9942 & 0,9966 & 0,9998 & 0,9990 \\
\hline \multirow{4}{*}{$\begin{array}{l}\text { Model } \\
\text { Herschela- } \\
\text { Bulkleya }\end{array}$} & $\begin{array}{l}\text { Granica } \\
\text { płynięcia [Pa] }\end{array}$ & 16,7607 & 1,4996 & 1,3982 & 2,0832 & 1,7703 & 23,3410 & 4,1346 & 6,3740 & 2,9339 & 1,3330 \\
\hline & $\begin{array}{l}\text { Współczynnik } \\
\text { konsystencji } \\
{\left[\mathrm{Pa} \cdot \mathrm{s}^{\mathrm{n}}\right]}\end{array}$ & 10,6937 & 0,0366 & 0,0468 & 0,1473 & 0,4751 & 18,1190 & 0,0416 & 0,0849 & 0,1782 & 0,3128 \\
\hline & $\begin{array}{l}\text { Wykładnik } \\
\text { potęgowy [-] }\end{array}$ & 0,3643 & 0,9829 & 0,9484 & 0,9008 & 0,7928 & 0,3092 & 0,9546 & 0,8490 & 0,8795 & 0,8277 \\
\hline & $\begin{array}{l}\text { Współczynnik } \\
\text { korelacji [-] }\end{array}$ & 0,9922 & 1,0000 & 0,9999 & 1,0000 & 0,9999 & 0,9955 & 0,9997 & 0,9999 & 0,9999 & 1,0000 \\
\hline
\end{tabular}

wyniki parametrów decydujących o efektywności uszczelniania zaczynów. Badania parametrów reologicznych polegały na określeniu modelu reologicznego zaczynów uszczelniających, czyli dopasowaniu krzywej reologicznej, która najlepiej opisywała wyniki pomiarów w układzie współrzędnych: naprężenia styczne $(\tau)$ - szybkość ścinania $(\gamma)[10,16]$. Obliczenia wykonano za pomocą modelu matematycznego, dopasowanego do krzywych płynięcia cieczy wiertniczych. W tablicy 3 zestawiono parametry reologiczne, oparte o model Cassona oraz Herschela-Bulkleya, ponieważ uzyskano w nich najwyższy współczynnik korelacji.

Analizowane zaczyny $\mathrm{z}$ dodatkiem dodatku antymigracyjnego podzielone zostały na dwie grupy. Pierwsza grupa to składy przeznaczone do uszczelniania kolumn rur okładzinowych na głębokościach od około $100 \mathrm{~m}$ do $600 \mathrm{~m}$, uszczelnianych w temperaturze oscylującej w okolicach $25^{\circ} \mathrm{C}$ i ciśnieniu około $3 \mathrm{MPa}$. Druga grupa receptur to składy przeznaczone do uszczelniania kolumn rur okładzinowych w głębokościach od $600 \mathrm{~m}$ do około $1300 \mathrm{~m}$, gdzie panują temperatury w zakresie około $50^{\circ} \mathrm{C}$ i ciśnienie w granicach $15 \mathrm{MPa}$. Na podstawie analizy uzyskanych wyników badań stwierdzono, że poddane badaniom dodatki przeciwmigracyjne nie powodują zmiany gęstości zaczynu cementowego (rysunek 3 ). Widoczne jest nieznaczne obniżenie wartości rozlewności zaczynów wskutek zastosowanych dodatków antymigracyjnych. Trend ten jest zauważalny zarówno w grupie receptur dla temperatury $25^{\circ} \mathrm{C}$, jak i w zaczynach przeznaczonych do uszczelniania otworów w temperaturze $50^{\circ} \mathrm{C}$ (rysunek 3). Również wartość odstoju wody została obniżona lub wyeliminowana wskutek zastosowania badanych dodatków antymigracyjnych. Jednak podczas analizy wyników badań widoczny jest wzrost wartości filtracji (w porównaniu do zaczynu bazowego Baz) wskutek zastosowania dodatku antymigracyjnego AM 1 oraz AM 2 (tablica 2 oraz rysunek 3). Dodatki antymigracyjne AM 3 oraz AM 4 powodują znaczne obniżenie filtracji, przy czym wartości w temperaturze $50^{\circ} \mathrm{C}$ są znacznie niższe niż w temperaturze $25^{\circ} \mathrm{C}$ (tablica 2 oraz rysunek 3). Analizując uzyskane czasy gęstnienia zaczynów zmodyfikowanych badanymi dodatkami antymigracyjnymi stwierdzono, że najlepsze właściwości wykazywały dodatki AM 3 oraz AM 4. Zastosowanie ich skutkowało

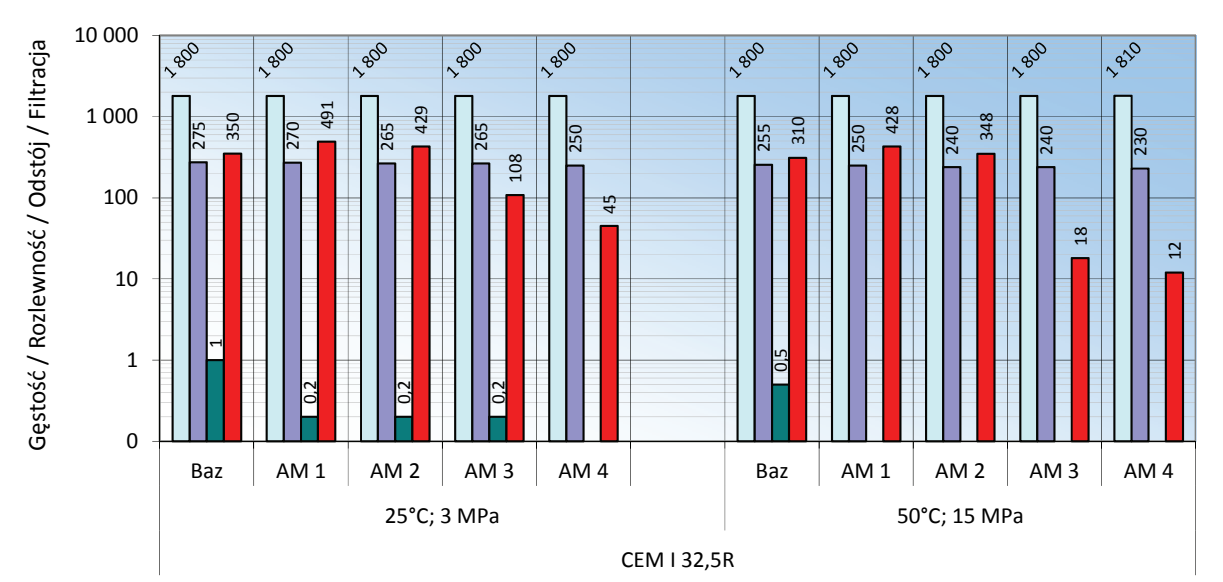

Oznaczenie zaczynu; warunki hydratacji; rodzaj spoiwa



Rys. 3. Zestawienie wyników gęstości, rozlewności, odstoju oraz filtracji zaczynów cementowych 




Oznaczenie zaczynu; warunki hydratacji; rodzaj spoiwa

Rys. 4. Zestawienie pomiarów czasu gęstnienia zaczynów cementowych

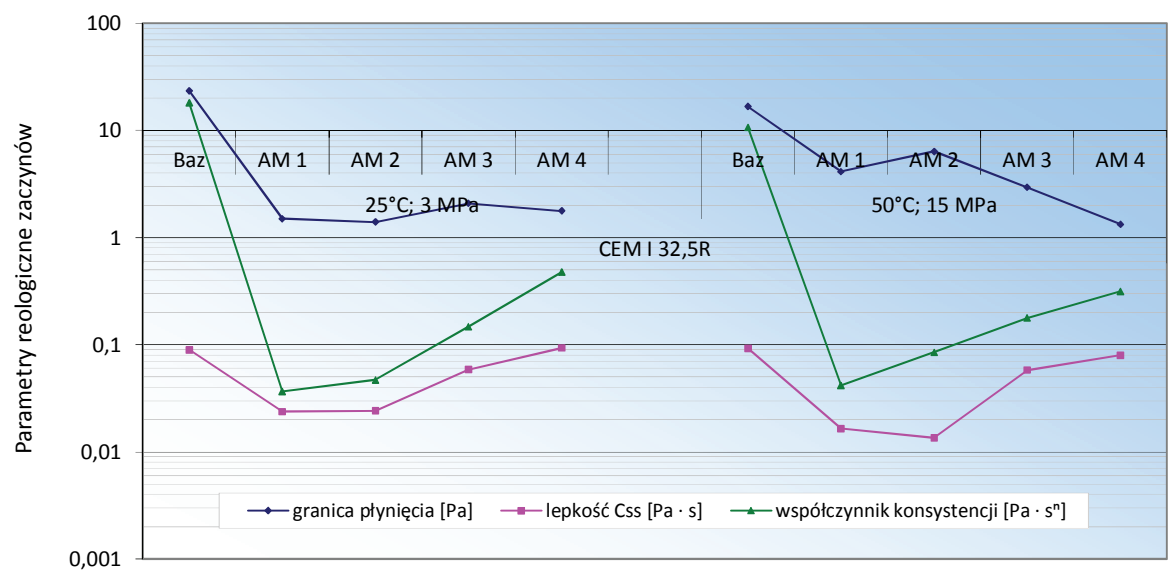

Oznaczenie zaczynu; warunki hydratacji; rodzaj spoiwa

Rys. 5. Zestawienie wyników badań parametrów reologicznych zaczynów cementowych

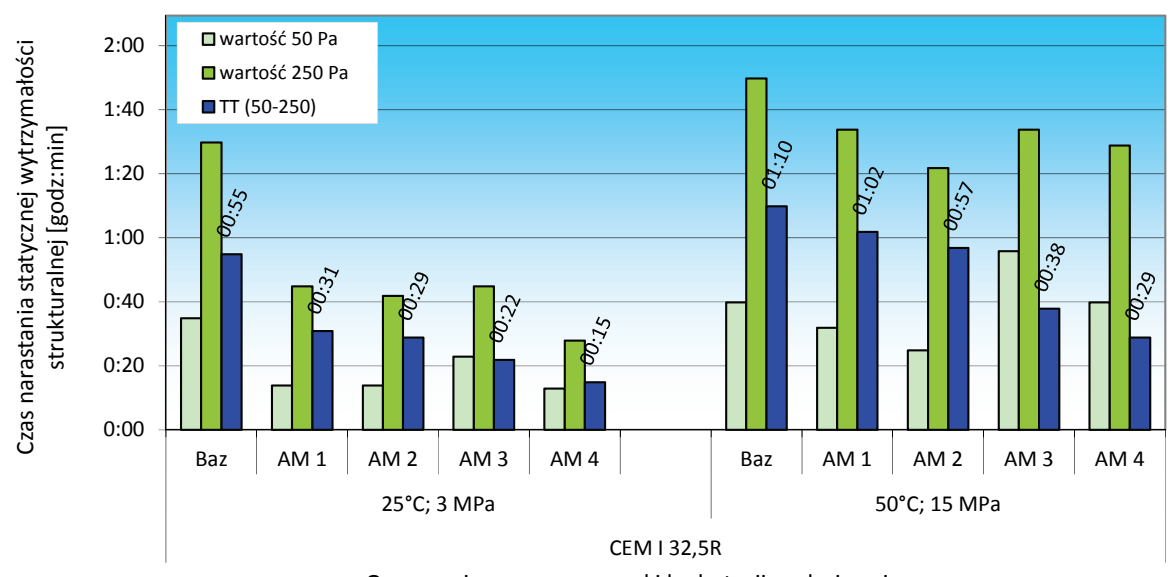

Oznaczenie zaczynu; warunki hydratacji; rodzaj spoiwa

Rys. 6. Zestawienie pomiarów wytrzymałości strukturalnej i czasu przejścia (ang. transition time) zaczynów cementowych parametrów reologicznych (rysunek 5), przy czym najmocniejsze upłynnienie zaczynu spowodowały dodatki AM 1 i AM 2. Na rysunku 6, który przedstawia wartości wytrzymałości strukturalnej zaczynów, widoczne jest skrócenie czasu przejścia (ang. transition time) od wartości $50 \mathrm{~Pa}$ do wartości 250 Pa wskutek zastosowanych dodatków. Przy czym dodatki antymigracyjne AM 3 oraz AM 4 spowodowały znacznie mocniejsze skrócenie czasu przejścia niż AM 1 oraz AM 2. Analizowane zaczyny z dodatkami przeciwdziałającymi migracji gazu wykazywały znacznie krótsze czasy przejścia w temperaturze $25^{\circ} \mathrm{C}$, niż w temperaturze $50^{\circ} \mathrm{C}$ (rysunek 6). Jest to bardzo korzystne ze względu na krótszy czas zabiegu cementowania otworów o mniejszej głębokości.

Ze względu na to, że prowadzone modyfikacje zaczynów analizowane były w aspekcie zwiększenia szczelności płaszcza cementowego, wykonane zostały dodatkowe badania struktury stwardniałych zaczynów. Wykonano badania porowatości za pomocą porozymetru rtęciowego oraz przepuszczalności dla gazu przy użyciu przepuszczalnościomierza gazowego. Próbki stwardniałych zaczynów cementowych poddano badaniom po 28 dniach hydratacji w warunkach otworopodobnych (temperatura i ciśnienie). Uzyskane wyniki badań porowatości oraz przepuszczalności stwardniałych zaczynów cementowych pozwoliły stwierdzić, że modyfikacje poprzez zastosowanie dodatków antymigracyjnych skutkują obniżeniem zarówno wartości porowatości, jak i przepuszczalności (rysunki 7 i 8). Obniżenie wartości porowatości w temperaturze $25^{\circ} \mathrm{C}$ wynosi $2,03 \%$ (w stosunku do wartości początkowej) natomiast $\mathrm{w}$ temperaturze $50^{\circ} \mathrm{C}$ wynosi $4,05 \%$ (od wartości bazowej). Przepuszczalność w temperaturze $25^{\circ} \mathrm{C}$ została obniżona $\mathrm{z}$ wartości $0,34 \mathrm{mD}$ do wartości $0,07 \mathrm{mD}$, natomiast $\mathrm{w}$ temperaturze tylko nieznacznym skróceniem czasu gęstnienia, jednak uzyskano znacznie krótszy odstęp czasowy od wartości $30 \mathrm{Bc}$ do wartości $100 \mathrm{Bc}$ (rysunek 3). Takie działanie badanych dodatków jest pożądane podczas uszczelniania złóż o podwyższonym ryzyku występowania migracji gazu. Zastosowanie dodatków antymigracyjnych spowodowało również obniżenie $50^{\circ} \mathrm{C} \mathrm{z}$ wartości $0,31 \mathrm{mD}$ do wartości $0,05 \mathrm{mD}$.

Konkluzje, jakie wyciągnięto na podstawie zrealizowanych prac badawczych pozwalają stwierdzić, że modyfikacje za pomocą innowacyjnych dodatków antymigracyjnych powodują zwiększenie szczelności płaszcza cementowego. Polimerowe dodatki, stosowane w celu przeciwdziałania migracji 


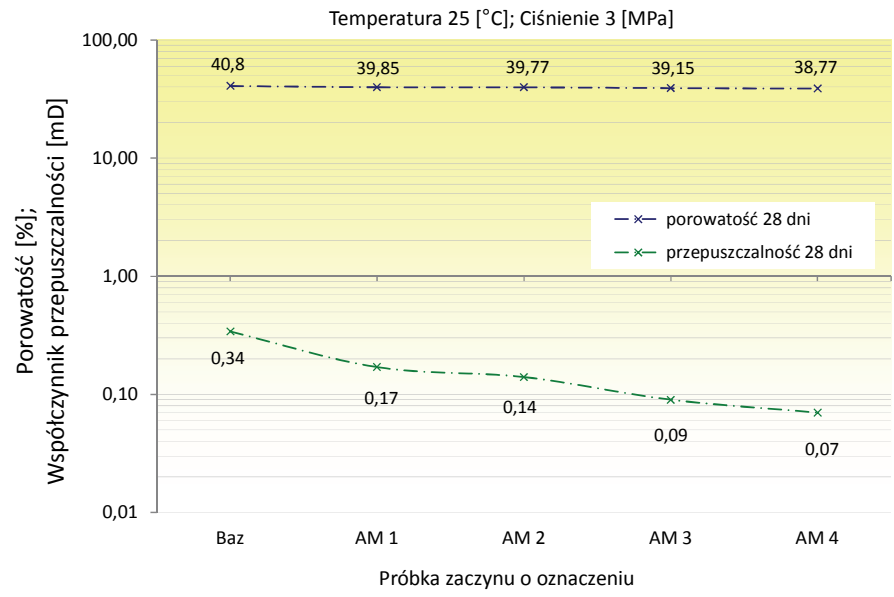

Rys. 7. Zestawienie wyników badań porowatości i przepuszczalności stwardniałych zaczynów cementowych (próbki dla: temperatury $25^{\circ} \mathrm{C}$, ciśnienia $3 \mathrm{MPa}$ )

gazu przez świeży zaczyn cementowy, powodują wyeliminowanie powstawiania odstoju wody, skrócenie czasu gęstnienia (głównie przejścia od wartości 30 Bc do wartości 100 Bc) oraz obniżenie parametrów reologicznych (lepkości plastycznej, współczynnika konsystencji i granicy płynięcia). Filtracja zaczynów może niekiedy ulec wzrostowi, jednak takie działanie nie deklasuje danego dodatku, ale należy wówczas zastosować odpowiedni rodzaj dodatku antyfiltracyjnego. Stosowanie dodatków przeciwdziałających migracji gazu skutkuje głównie skróceniem czasu budowania statycznej wytrzymałości strukturalnej (przejście od wartości 50 Pa do wartości 250 Pa).

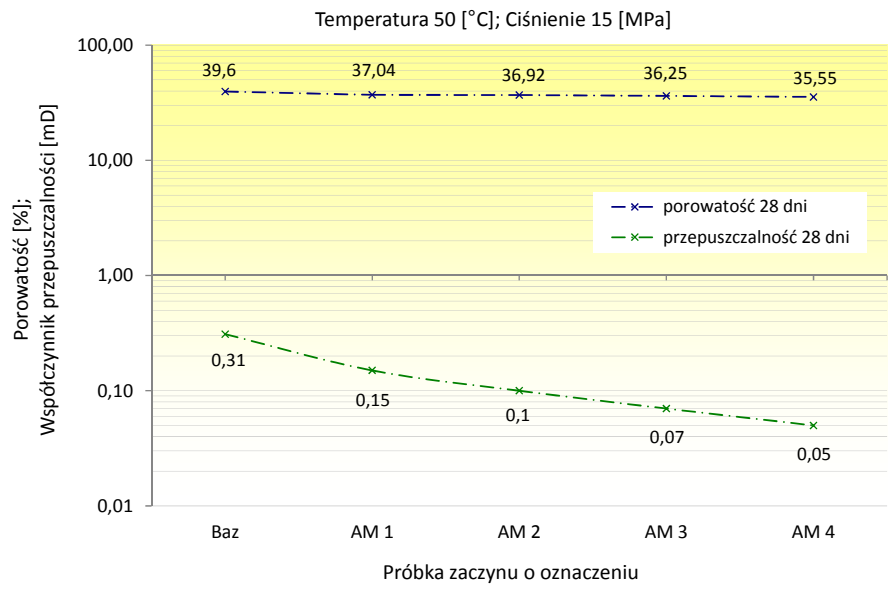

Rys. 8. Zestawienie wyników badań porowatości i przepuszczalności stwardniałych zaczynów cementowych (próbki dla: temperatury $50^{\circ} \mathrm{C}$, ciśnienia $15 \mathrm{MPa}$ )

Rozpatrując obecność dodatków przeciwdziałających migracji gazu w aspekcie zwiększenia szczelności płaszcza cementowego, należy wspomnieć o obniżeniu porowatości i przepuszczalności zaczynów wskutek zastosowanych dodatków antymigracyjnych. Taki wpływ na strukturę stwardniałego zaczynu cementowego skutkuje zwiększeniem szczelności w długoletnim czasie eksploatacji odwiertu. Bardziej skompaktowana i nieprzepuszczalna mikrostruktura stwardniałego zaczynu wykazuje większą odporność korozyjną oraz trwałość, co jest warunkiem niezbędnym przy projektowaniu receptur zaczynów uszczelniających.

\section{Wnioski}

Na podstawie uzyskanych wyników badań wyciągnięto następujące wnioski:

1. Stosowane dodatki przeciwdziałające migracji gazu nie powodują zmiany gęstości zaczynu cementowego, a ich użycie skutkuje wyeliminowaniem odstoju wody.

2. Działanie dodatków antymigracyjnych wpływa na zwiększenie szczelności płaszcza cementowego, poprzez dokładniejsze wypełnienie cementowanej przestrzeni pierścieniowej i lepsze usunięcie pozostałości niewypłukanego osadu filtracyjnego oraz uzyskanie turbulentnego przepływu cieczy wskutek niższych wartości parametrów reologicznych.

3. Uzyskanie krótkiego czasu budowania statycznej wytrzymałości strukturalnej oraz krótkiego odstępu czasowego od wartości 30Bc do wartości $100 \mathrm{Bc}$ podczas badania czasu gęstnienia pozwala stwierdzić, że dodatki antymigracyjne wpływają na zwiększenie szczelności płaszcza cementowego. Jest to związane z pewnego rodzaju ,zaciskaniem” ewentualnych dróg migracji gazu, mogących tworzyć się po wtłoczeniu zaczynu w cementowaną przestrzeń pierścieniową.
4. Stosowanie dodatków antymigracyjnych, pomimo korzystnego wpływu na parametry technologiczne zaczynu, może powodować wzrost wartości jego filtracji zaczynu. Takie zachowanie wymaga zastosowania dodatków antyfiltracyjnych.

5. Na podstawie analizy uzyskanych wyników badań stwierdzono, że otrzymane w efekcie prowadzonych modyfikacji receptury i powstałe według nich stwardniałe zaczyny cementowe powodują wzrost szczelności płaszcza cementowego wskutek uzyskania nieprzepuszczalnej mikrostruktury, charakteryzującej się obniżoną wartością porowatości.

6. Należy mieć na uwadze, że na zwiększenie szczelności płaszcza cementowego wpływa wiele czynników. Powyższe wręcz wymusza prowadzenie analiz wyników badań receptur w odniesieniu do konkretnych warunków geologiczno-technicznych. Pomocą podczas rozwiązywania tego rodzaju problemów jest ciągłe prowadzenie badań zaczynów typowanych do zabiegu cementowania oraz ich modyfikacja. Oczywiste jest to, że tego rodzaju badania należy wykonywać w laboratorium, na specjalistycznej, przeznaczonej do tego celu aparaturze. 
Prosimy cytować jako: Nafta-Gaz 2018, nr 6, s. 457-464, DOI: 10.18668/NG.2018.06.06

Artykuł nadesłano do Redakcji 16.03.2018 r. Zatwierdzono do druku 23.04.2018 r.

Artykuł powstał na podstawie pracy badawczej pt.: Analiza możliwości poprawy efektywności uszczelniania rur okładzinowych poprzez zastosowanie nowych dodatków do zaczynów cementowych - praca INiG - PIB na zlecenie MNiSW, nr zlecenia: 35/KW/15, nr archiwalny: DK-4100/35/15 oraz na podstawie badań własnych.

\section{Literatura}

[1] Barron A.R.: Hydratation of Portland Cement. http://cnx.org/ content/m16447/latest/ (dostęp: 26.01.2014).

[2] Bonett A., Pafitis D.: Getting to the Root of Gas Migration. Oilfield Review, Spring 1996, vol. 8, nr 1, s. 36-49.

[3] Dębińska E.: Niekonwencjonalne zaczyny cementowe z dodatkiem nanokrzemionki. Nafta-Gaz 2015, nr 5, s. 290-300.

[4] Dębińska E.: Wyznaczanie statycznej wytrzymałości strukturalnej $i$ wczesnej wytrzymałości mechanicznej zaczynów cementowych. Nafta-Gaz 2013, nr 2, s. 134-142.

[5] Gawlik P., Szymczak M.: Migracje gazowe w przestrzeniach międzyrurowych otworów realizowanych na przedgórzu Karpat. Nafta-Gaz 2006, nr 7-8, s. 349-358.

[6] Habrat S., Raczkowski J., Zawada S.: Technika i technologia cementowań w wiertnictwie. Wydawnictwo Geologiczne, Warszawa 1980, $498 \mathrm{~s}$.

[7] Kremieniewski M.: Ocena przepuszczalności kamieni cementowych pod katem ograniczenia migracji gazu. Prace Naukowe INiG - PIB 2014, nr 196, 155 s.

[8] Kremieniewski M.: Ograniczenie ekshalacji gazu w otworach wiertniczych poprzez modyfikację receptur oraz ksztattowanie się struktury stwardniałych zaczynów cementowych. Prace Naukowe INiG - PIB 2016, nr 199, 390 s.

[9] Kremieniewski M.: Poprawa stabilności sedymentacyjnej zaczynów cementowych. Prace Naukowe INiG - PIB 2017, nr 216, 145 s.

[10] Kremieniewski M., Rzepka M., Dębińska E.: Statyczna wytrzymałość strukturalna zaczynów przeznaczonych do uszczelniania otworów o podwyższonym ryzyku występowania migracji gazu. Nafta-Gaz 2014, nr 9, s. 608-616.

[11] Kremieniewski M., Rzepka M., Stryczek S., Wiśniowski M.: Comparison of gas migration test and building structural strength of slurry in the aspect of limiting gas invasion. AGH Drilling, Oil, Gas Quarterly 2016, vol. 33, s. 595-608.

[12] Kremieniewski M., Rzepka M.: Celowość prowadzenia prac badawczych nad nowymi środkami obniżajacymi filtrację zaczynów cementowych. Nafta-Gaz 2017, nr 8, s. 583-590, DOI: 10.18668/NG.2017.08.05.

[13] Kremieniewski M., Rzepka M.: Przyczyny i skutki przepływu gazu w zacementowanej przestrzeni pierścieniowej otworu wiertniczego oraz metody zapobiegania temu zjawisku. Nafta-Gaz 2016, nr 9, s. 722-728, DOI: 10.18668/NG.2016.09.06.
[14] Kremieniewski M., Rzepka M.: Zaczyny typu Gas-Stop przeznaczone do uszczelniania otworów kierunkowych $i$ horyzontalnych. Wiadomości Naftowe i Gazownicze 2013, nr 9, s. 4-9.

[15] Kremieniewski M., Rzepka M.: Zapobieganie niekontrolowanym wyptywom gazu z otworów wiertniczych na etapie projektowania zaczynów cementowych. Wiadomości Naftowe i Gazownicze 2015, nr 11, s. 4-8.

[16] Kremieniewski M., Stryczek S., Wiśniowski R.: Correlation of parameters describing microstructure of hardened cement slurry for the purpose of increasing tightness of cement mantle. AGH Drilling, Oil, Gas Quarterly 2014, vol. 31, nr 3, s. 413-420.

[17] Mammadbayli R., Greener J.: Foamed cement successfully applied in shallow water environment in Caspian Sea. Drilling Contractor 2006, nr 9/10, s. 64-69.

[18] Nelson E.B. et al.: Well Cementing. Schlumberger Educational Service, Houston, Texas 1990, 773 s.

[19] Rogers M.J., Dillenbeck R.L., Eid R.N.: Transition time of cement slurries, definitions and misconceptions, related to annular fluid migration. SPE Annual Technical Conference and Exhibition, Houston, Texas 26-29.09.2004.

[20] Rzeczpospolita tupkowa. Studium wiedzy o gazie z formacji tupkowych. Praca zbiorowa. Prace Naukowe INiG 2012, nr 183, $310 \mathrm{~s}$.

[21] Stryczek S., Gonet A.: Kierunki ograniczania migracji gazu z przestrzeni pierścieniowej otworu wiertniczego. WUG: Bezpieczeństwo Pracy i Ochrona Środowiska w Górnictwie 2005, nr 3, s. 10-13.

[22] Stryczek S., Gonet A.: Wymagania odnośnie zaczynów uszczelniajacych stosowanych $w$ technologiach wiertniczych. Sympozjum Naukowo-Techniczne „Cementy w budownictwie, robotach wiertniczych i inżynieryjnych oraz hydrotechnice”, Piła-Płotki 2001.

[23] Stryczek S., Wiśniowski R., Uliasz-Misiak B., Złotkowski A., Kotwica Ł., Rzepka M., Kremieniewski M.: Studia nad doborem zaczynów uszczelniajacych $w$ warunkach wierceń $w$ basenie pomorskim. Wydawnictwo AGH 2016, $222 \mathrm{~s}$.

[24] Uliasz M., Kremieniewski M.: Minimalizacja możliwości wystapienia migracji gazu w rejonie przedgórza Karpat. Wiadomości Naftowe i Gazownicze 2015, nr 8, s. 18-22.

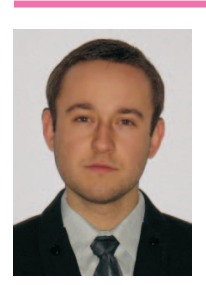

Dr inż. Marcin KREMIENIEWSKI

Adiunkt w Zakładzie Technologii Wiercenia.

Instytut Nafty i Gazu - Państwowy Instytut Badawczy

ul. Lubicz $25 \mathrm{~A}$

31-503 Kraków

E-mail: marcin.kremieniewski@inig.pl

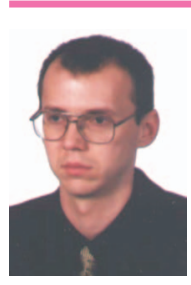

Dr inż. Marcin RZEPKA

Kierownik Laboratorium Zaczynów Uszczelniających w Zakładzie Technologii Wiercenia.

Instytut Nafty i Gazu - Państwowy Instytut Badawczy ul. Lubicz 25 A

31-503 Kraków

E-mail: marcin.rzepka@inig.pl 